\title{
Identification of Landslide-Prone Subsoil Using Wenner Configuration Geoelectric Method in Gayamharjo Village, Prambanan District, Sleman Regency
}

\author{
Najila Tihurua $^{1 *}$, Thaqibul Fikri Niyartama ${ }^{1}$, Yunita Eri Setyaningrum ${ }^{2}$, Qurrotul Uyun ${ }^{2}$ \\ ${ }^{1}$ Physics Department, ${ }^{2}$ Physics Education Department, Faculty of Science and Technology UIN Sunan Kalijaga \\ J1. Marsda Adisucipto No. 1 Yogyakarta 55281, Indonesia. Tel. + 62-274-540971, Fax. + 62-274-519739 \\ Email: najila21tihurua@gmail.com
}

\begin{abstract}
Landslides occur due to the field of slip. Identification of Soil Landslide Identification Using Geolistrik Method The Wenner configuration has been done in Gayamharjo Village, Prambanan Sub-district, Sleman District. This study aims to determine the structure of subsurface rocks and identify the field of ground slip in the landslide prone areas in the study area. Measurements were made as many as 3 trajectories, the smallest spaced between 20 meters electrode with 300 meters of track length. The tool used is Syscal Jr Switch-48. Data processing uses RES2DINV software that produces 2D subsurface modeling. The results of the interpretation showed that the location of the study identified the constituent rock consisting of three layers of subsurface rocks $(1,36$ to 6,86$) \Omega \mathrm{m}$, sandstone (15,4 to 34,6) $\Omega \mathrm{m}$, and andesite rocks (77, 8 to 393) $\Omega \mathrm{m}$. In the three trajectories of the research area, there is a slip field with the potential for landslide: track 1 at point 40 s.d. 80 with a depth of 37 m, track 2 at point 220 s.d. 240 with depth 26 m, path 3 at point 100 s.d. 140 with a depth of $37 \mathrm{~m}$.
\end{abstract}

Keywords: Landslide, Prambanan, Resistivity

\section{INTRODUCTION}

Landslide is a common problem occured in the area with steep slopes (Darsono, et al., 2012). Landslide or commonly known as soil or rock movement is a geological phenomenon which occurs due to mass movements of rock or soil of various types such as falling rocks or large lumps of soil (Wahyono, et al., 2011). Landslides can occur naturally if they were caused by natural factors. Landslides causes disaster when they harm humans in social, economy and environmental aspects. This phenomenon are affected by land usage, topography, geological conditions, slope, and climate that cause rainfall, humidity and temperature. The information from these factors will be taken into consideration in the study of landslide vulnerabilities.

Yogyakarta Special Region is one of the provinces with landslide-prone. One of the landslide-prone area in Yogyakarta is in Gayamharjo Village, Prambanan District, Sleman Regency. Based on the information of BPBD (Regional Disaster Management Agency) Sleman Regency, landslides often occur in the hills of Prambanan District in the areas which has slopes with more than 15 s.d. 40 degrees and weak soil binding capacity.

Gayamharjo Village, which has the potential of landslide disasters, includes Kali Nongko Lor, Lemahabang and Dawung. Kali Nongko Lor is one of the villages that was stricken by landslides on February 5, 2017. The cliffs are seven meters high and eight meters wide. It damages a house and move the road of the village. According to BPBD (Regional Disaster
Management Agency), Sleman Regency, a landslide that occurred in Kali Nongko Lor RT 01 RW 14 Gayamharjo was unpredictable, because the area was not included in the map of landslide area.

The application of resistivity geophysics method has been widely used for surveying and exploring natural resources, but it can also be used to determine slip areas that are estimated to be the cause of landslides (Griffiths and Barker, 1993). The resistivity geoelectric method can produce the image of the subsurface rock layer based on the resistivity value of the rock type that constitutes the layer which is estimated to be the cause of landslides (Telford, et al., 1976).

This study used Wenner configuration geoelectric method to determine the structure and layer of subsurface soils based on the rock resistivity level, in Gayamharjo village, Prambanan District, Sleman Regency. The information about the soil resistivity value is used to determine the soil layer in landslideprone areas which can be used as a reference in the development of the area in Gayamharjo and the surrounding areas. This method is more effective and suitable to explore up to several meters below the earth's surface, furthermore, the use of the method does not damage the environment and relatively cheaper on the operating costs (Darsono, 2012). At last, to find out the resistivity value and rock layer in that location, it is necessary to do research on "Identification of Landslide-Prone Subsoil Using Wenner Configuration Geoelectric Method in Gayamharjo Village, Prambanan District, Sleman Regency". 


\section{MATERIALS AND METHODS}

The work procedure used in this study is divided into four stages which are survey design stage, data acquisition, 2D data processing, and data interpretation. The research preparation phase identifies landslidesprone subsoil by collecting geological maps, topographic maps and tools used. The Geological maps are used for stratigraphic information and geological structures, while topographic maps is to inform the state of the earth in the study area. The research tool is used to measure research data. Based on geological information obtained from literature and observations in the field, then a survey design is made to facilitate data retrieval, the first stage determines the location of the measurement point and then makes the track according to the desired target. This study consisted of 3 trajectories with the smallest spacing between electrodes of 20 meters and a trajectory length of 300 meters.

Data collection in this study was done using the Wenner configuration geoelectric method. The result based on Wenner's measurement in this study are $\mathrm{V}$ (potential difference) and I (current). Data retrieval is carried out using current electrodes and potential electrodes in the measurement consisting of three trajectories (each path consists of 16 points) with each trajectory along a 300 meter path, from each path has a current range of electrodes and potential electrodes of 20 meter and distance between tracks 40 meters. Data processing in this study uses software such as Microsoft Excel that is used to create data retrieval forms and data calculations, notepad is used to input data with the file type "*dat" so that it can be read for Res2dinv, and Res2dinv is used for 2D data processing so that the model is obtained resistivity inversion. Interpretation of data in the study based on the rock resistivity characteristics in $2 \mathrm{D}$ models. The results of the $2 \mathrm{D}$ research model are correlated with supporting data such as namely geology and outcrops of the study area.

\section{RESULTS AND DISCUSSION}

The data collection process is carried out on 3 different tracks and each track is located at a different point. Each track has a length of 300 meters. From each track has a current range of electrodes and the shortest potential electrode is 20 meters and the longest is 100 meters, the study consists of $\mathrm{n}=8$, as shown in the measurement realization map Figure 1.

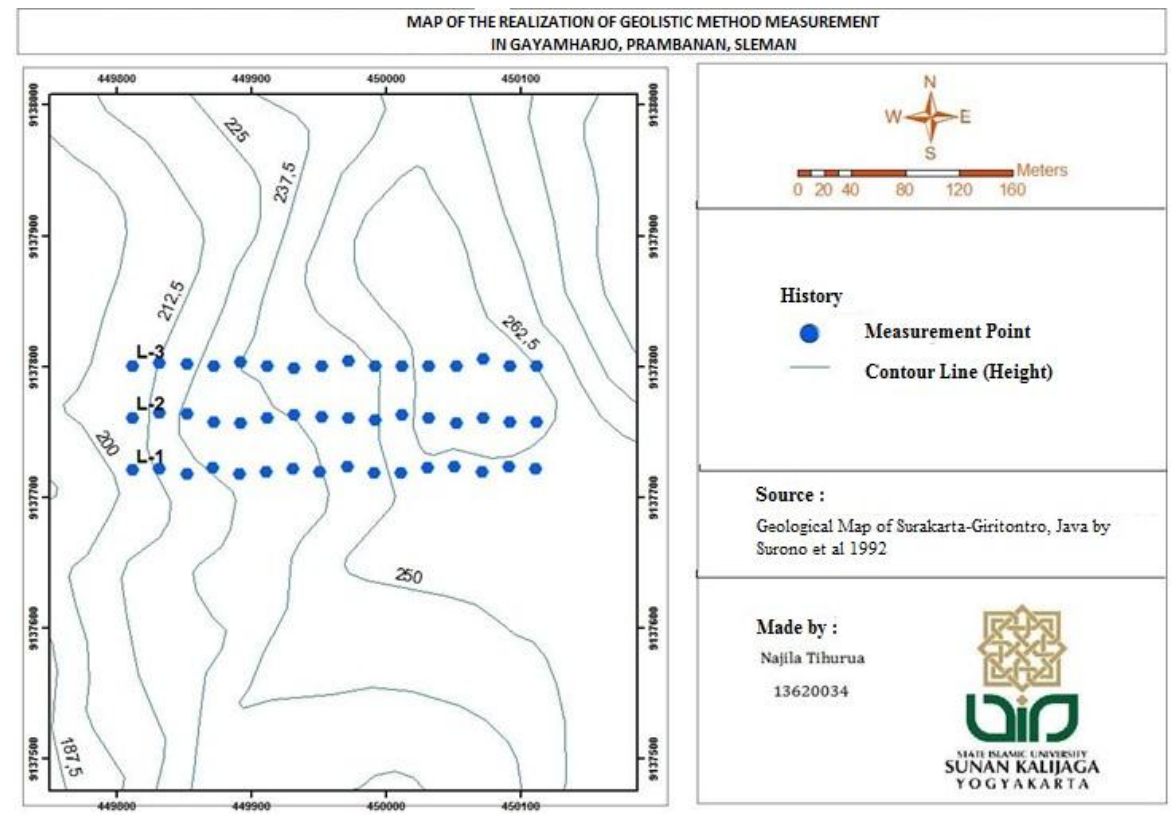

Figure 1. Map of realization of measurement points.

The measurement results of the data obtained from the tool include flowing current I (amperes), invoice V (volts), resistance $\mathrm{R}$ (ohms). Natural and weather conditions affect the measurement process and results. The natural state determines the direction of the stretch that might be carried out when the measurement takes place. As well as weather conditions that can affect the fluid contained in the soil layer so that it affects the electrical properties of the rock. 
The next stage is the data processing process in the Res2dinv software which in the process produces a 2D section. This is the first step to get the results of research on track 1 , track 2 , and track 3 for all kinds of images in data processing Figure 2, namely:

1. Apparent resistivity pseudesection. This cross section illustrates the resistivity value when making measurements in the field.

2. The cross section of the apparent resistivity calculation obtained from the result of resistivity has been multiplied by the geometry factor $(\mathrm{K})$, this can be said to be modeling of the apparent resistivity value.

3. The inversion cross section which is the actual resistivity value.

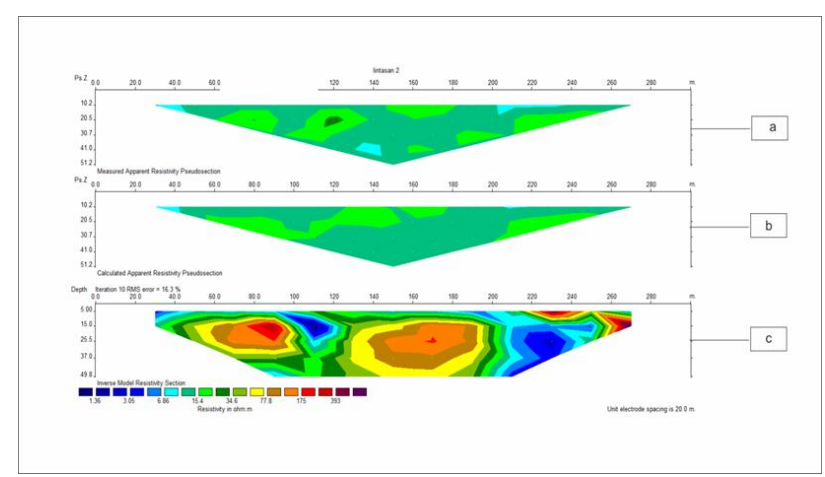

Figure 2. 2D data processing (a) Pseudosection resistivity, (b) Pseudo resistivity calculation, (c) The result of resistivity inversion.

\section{D Resistivity Inversion Model Results}

The result of the res2dinv software processing is the 2dimensional cross-sectional model, the cross-section illustrates the actual resistivity and depth values. The following are 2-dimensional cross-sectional models on 3 measurement tracks.

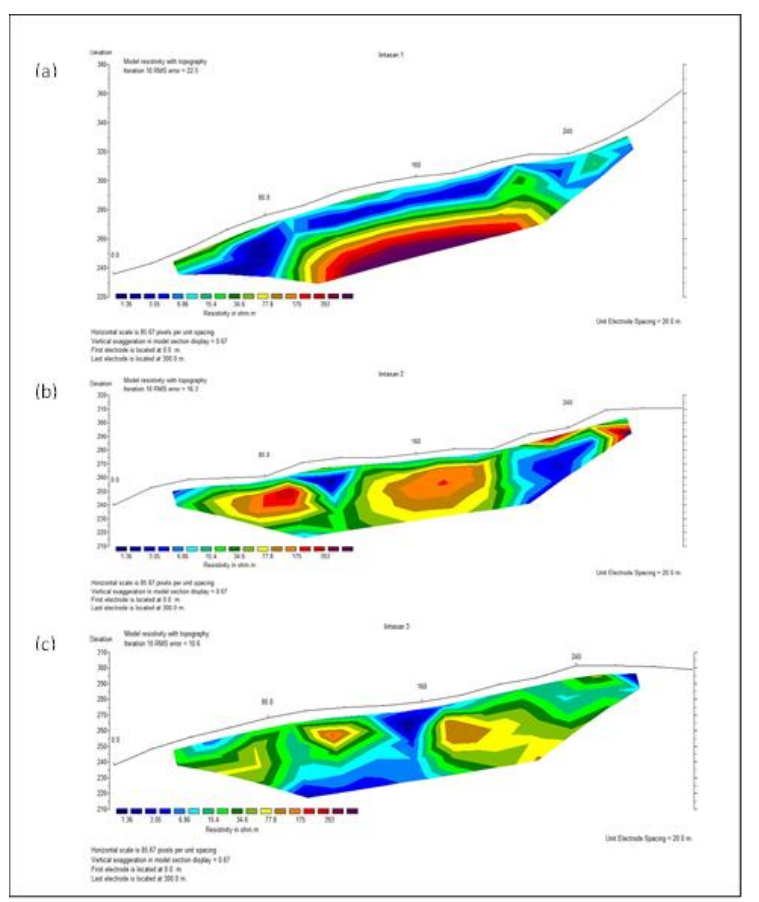

Figure 3. 2D inversion model from; (a) Track 1, (b) Track 2, (c) Track 3.

\section{Discussion}

Based on the cross section in Figure 3 above the type of resistivity arrangement in (a) Track 1 is estimated to have three subsurface layers. The blue color has a resistivity value between 1.36 up to $6.86 \mathrm{ohm}$ meters, interpreted as clay stone found in the photo in the research location shown in Figure 3 (a) the green color has a resistivity value between 15.4 up to $34.6 \mathrm{ohm}$ meters interpreted as sandstone. Furthermore, the red color has a resistivity value between 77.8 up to 393 ohm meters are interpreted as andesite rock. On track 1 there are several points that have the potential for rotational landslides to occur. As at point 40 up to 80 meters, with a depth of 37 meters with a subsurface arrangement consisting of sandstones below which there is clay stone, on track 1 there are sandstone and clay stone outcrops as shown in Figure 2. Point 100 up to 220 is an area there is no potential for landslide, where along this point there are andesite rocks scattered up to a depth of 25.5 meters, which are obtained from processing by using Res 2 dinv software.

Track 2 is at an altitude of 240 meters, above sea level. Based on figure 3, it can be seen that (b) Track 2 consists of three different rock types with a resistivity value between 1.36 up to 393 ohm meters. The rocks that make up this trajectory are clay stone with a resistivity value of 1.36 up to $6.86 \mathrm{ohm}$ meters scattered along the subsurface trajectory, sandstone with varying resistivity values of 15.4 to $34.6 \mathrm{ohm}$ meter which is at 0 depth. 15 meters below the surface, and andesite with a variation of resistivity values of 26.5 to $64.0 \mathrm{ohm}$ meter. The existence of andesite stone is very dominant in this trajectory to a depth of 49.8 meters, based on processing using Res2dinv software. This track has a point that has the potential to landslide, which is at point 220 up to 240 meters with a depth of 26 meters, generally ground motion occurs in the area around the contact of the inertia between clay stone with sandstone inserts (Ristianto, 2007).

On track 3, we get an estimate of the information on the subsurface layers and the type of rock based on the resistivity values of these values which are representations of subsurface rock conditions. The blue color has a resistivity value that ranges between 1.36 up to $6.86 \mathrm{ohm}$ meters, which is interpreted as clay stone, and the green color has a resistivity value between 15.4 up to $34.6 \mathrm{ohm}$ meters are interpreted as sandstones and yellow which has a resistivity value between 77.8 up to $393 \mathrm{ohm}$ meters are interpreted as andesite as shown in Figure 4.10 , the average slope angle of the three tracks is $3^{\circ}$ up to $32^{\circ}$. Track 3 found a slip field that has a potential for landslides. The slip field is at point $100 \mathrm{up}$ to 140 meters at a depth of 37 up to 49.8 meters, where at that point there is sandstone above the clay stone.

\section{CONCLUSIONS}

Based on the result of the identification carried out in Gayamharjo Village, Prambanan District, Sleman Reg- 
ency in general can be concluded as follows:

1. The subsurface structure of the study area is identified as having three subsurface layers. Resistivity between 1.36 up to $6.86 \mathrm{ohm}$ meters were identified as clay stone, resistivity between 15.4 up to $34.6 \mathrm{ohm}$ meters are identified as sandstones, resistivity is between 77.8 up to 393 were identified as Andesite stones.

2. Based on the three trajectories of measurement in the study area, there are ground slip areas that have the potential to landslide on the three trajectories, namely watertight clay stone on track 1 at point 40 up to 80 meters with a depth of $37 \mathrm{~m}$, path 2 at point 220 up to 240 meters with a depth of $26 \mathrm{~m}$, and track 3 at point 100 up to 140 meters at a depth of $37 \mathrm{~m}$.

\section{ACKNOWLEDGMENTS}

The author would like to thank to the management of apprenticeship program of faculty of science and technology for guidance during the research, to the management of biology, medicine and natural product chemistry \& kaunia journal for assistance in paper writing.

\section{REFERENCES}

Anonim. 2008. Penata Ruang Bab 1. www.penataruang.net/taru/nspm/29/isi.pdf (Downloaded on date 25 February 2018).

Bammelen, R.W.V. 1949. "The Geologi Indonesia". The Hangue Martinus, Australia.

Bothe, A.C.H.D. 1928. "Jiwo Hill and Southern range". Excurtion Fourt guide, Pasific Science Congress, Bandung.

Burger. 2016. "Keunggulan Konfigurasi Wenner". http://digilib.its.ac.id/public ITS underground.

Darsono, Bambang, N. dan Budi, E. 2012. "Identifikasi Bidang Gelincir Pemicu Bencana Tanah Longsor Dengan Metode Resistivitas 2 Dimensi Di Desa Pablengan Kecamatan Matesih Kabupaten Karanganyar". Indonesian Journal of Applied Physics. Vol.2 No.1 halaman 51

Deja, F.R. 2015. "Analisis Data Mikroseismik Untuk Pemetaan Daerah Rawan Longsor Di Daerah Dieng Kulon, Desa Karang Tengah, Kecamatan Batur, Kabupaten Banjarnegara Jawa Tengah". Skripsi. Yogyakarta: UGM.

ESDM. 2007. "Jenis Tanah Longsor dan Faktor Penyebabnya". Diakses 8 Desember 2015 pada http://www.esdm.go.id

Fajriah, L. 2016. "Tingkat Kerawanan Tanah Longsor Di Kecamatan Prambanan Kabupaten Sleman Menggunakan Sistem Informasi Geografis". Program Studi Pendidikan Geografi: Universitas Negeri Yogyakarta.

Griffiths, D.H. dan Barker, R.D. 1993. "Two Dimensional Resistivity Imaging and Modelling in Areas of Complex Geology". Journal of Applied Geophysics.

Hariyatmo, H.C. $2006 . \quad$ "Penanganan Tanah Longsor Lahan dan Erosi". Yogyakarta" : Gadjah Mada University Press.

Hendrajaya dan Arif, I. 1990. "Monograf, Geolistrik Tahanan Jenis". Laboratorium Fisika Bumi ITB: Bandung.

Husein, S. dan Srijono. 2007. "Tinjauan Geomorfologi Pegunungan Selatan DIY/Jawa Tengah: Telaah Peran Faktor Endogenik Dan Eksogenik Dalam Proses Pembentukan Pegunungan”. Prosiding
Seminar Potensi Geologi Pegunungan Selatan dalam Pengembangan Wilayah, Pusat Survei Geologi : Yogyakarta.

Irayani, Z., Permanajati, I., Haryadi, A., Wihantoro, dan Aziz, N.A. 2016. "Investigasi Bidang Gelincir Tanah Longsor Dengan Metode Tahanan Jenis dan Pengujian Sifat Plastisitas Tanah (Studi Kasus di Bukit Pawinihan, Sijeruk, Banjarmangu, Banjarnegara)". Jurusan Fisika Fakultas Matematika dan Ilmu Pengetahuan Alam, Universitas Jendral Soedirman: Purbalingga.

Karnawati, D. 2005. "Bencana Alam Gerakan Massa Tanah di Indonesia dan Upaya Penanggulangannya”. Yogyakarta: ISBN 97995811-3-3.

Loke, M.H. 1994. "The inversion of two-dimensional resistivity data". Unpubl. PhD thesis, University Of Birmingham.

Mahardita, M.S. 2016. "Analisis Kinematik dan Stabilitas Lereng Batuan Pada Desa Bokoharjo Kecamatan Prambanan, Kabupaten Sleman, DIY”. Tugas Akhir. Yogyakarta: UGM.

Nugrahani. 2015. "Aplikasi Metode Geolistrik Tahanan Jenis 2D Konfigurasi Wenner Untuk Penentuan Bidang Gelincir Tanah Longsor di Desa Glanggang, Kecamatan Pakisaji, Kab. Malang”. Skripsi, Jurusan Fisika Fakultas Matematika dan Ilmu Pengetahuan Alam: Universitas Negeri Malang.

Prasetyadi, C., Sudarno, I., Indranadi, V.B., dan Surono. 2011. "Pola dan Genesa Struktur Geologi Pegunungan Selatan". Provinsi Daerah Istimewa Yogyakarta dan Provinsi Jawa Tengah: Jurnal Sumber Daya Geologi.

Priyantari, N. dan Wahyono, C., 2005. "Penentuan Bidang Gelincir Tanah Longsor Berdasarkan Sifat Kelistrikan Bumi (Determination Of Slip Surface Based On Geoelectricity Properties)". www.mipa.unej.ac.id/data/vol6no2/nurul-pdf.

Prih, H.,Ratag, A.M., Karnawati, D., Rizal, S.D., Surono, Sutardi, M., Triwibowo, Wasiati, A., Yusharmen, Pariatmono, Triutomo, S., dan Widjaja, W. 2007. Pengenalan Karakteristik Bencana dan Upaya Mitigasinya di Indonesia. Edisi II. Direktorat Mitigasi Lakhar Bakornas PB: Jakarta dan Sons Ltd: New York.

Rahardjo, W., Sukandarrumidi, dan Rosidi, H.M.S., 1995. "Peta Geologi Lembar Yogyakarta”. Skala 1:100.000.

Restika, S.M. 2016. "Identifikasi Bidang Gelincir Menggunakan Metode Geolistrik Konfigurasi Dipole-Dipole di Saluran Irigasi Km 15,9 Kalibawang, Kulon Progo". Skripsi, program Studi Geofisika: Universitas Gadja Mada.

Ristianto, D. 2007. "Penentuan Resistivitas Tanah Pada Zona Labil Dengan Aplikasi Geolistrik Metode Tahanan Jenis Konfigurasi Schlumberger (Studi Kasus Di Desa Bambankerep, Kecamatan Ngaliyan, Kota Semarang, Jawa Tengah)”. Semarang: Unnes (tidak dipublikasikan).

Sharma, P.V. 1997. "Environmental an Engineering Geophysics". Cambridge University Press

Sartono, S. 1964. "Stratigraphy And Sedimention Of The Eastern Most Part Of Gunung Sewu (East Java)". Publikasi Teknik 1: 30 s.d. 34. Bandung: Fakultas Teknik ITB.

Sulistyowati, 2009. "Penentuan Letak dan Kedalaman Akuifer Air Tanah dengan Geolistrik Metode Tahanan Jenis". Tugas akhir. Tidak Diterbitkan. Semarang: Universitas Negeri Semarang.

Sumarso dan Ismoyowati, T. 1975. "Contribution to The Stratigraphy of The Jiwo Hills and Their Southern Surrondings (Central Java)". Proceedings Indonesian Petroleum Association 4th Annual Convention, vol. 2, pp 19 s.d. 26, 2006.

Sumosusastro, S. 1956. "A Contribution to the Geology of the Eastern Djiwo Hills and The Southern Range in Central Java". Majalah Pengetahuan Alam Indonesia: Bandung, pp. 115 - 133.

Sudarno, I. 2007. "Evolusi Tegasan Purba dan Mekanisme Pembentukan Sesar di Pegunungan Selatan Bagian Barat DIY dan Sekitarnya". Prosiding Workshop Geologi Pegunungan Selatan 2007, (No. 38), hal 89-103.

Surono. 2009. "Litostratigrafi Pegunungan Selatan Bagian Timur Daerah Istimewa Yogyakarta dan Jawa Tengah". Jurnal Sumber Daya Geologi, Vol 19(No.3).

Surono, Toha, B., Sudarno, I. 1992. "Peta Geologi Lembar Surakarta-Girintolo skala 1:100.000”. Bandung: Pusat Penelitian dan Pengembangan Geologi.

Telford W.M., Geldart L.P., dan Sheriff R.E. 1990. "Applied Geophysics. Edisi 2. Cambridge": Cambridge University Press.

Tim Penyusun. 2008. "Buku Panduan Workshop Geofisika". Malang: Universitas Brawijaya. 
Wahyono, S.C., Hidayat, C.A., Pariadi, R.F, Novianti, R.K., Dewi dan Minarto, O. 2011. "Aplikasi Metode Tahanan Jenis 2D untuk Mengidentifikasi Potensi Daerah Rawan Longsor di Gunung Kupang, Banjarbaru”. Jurnal Ilmiah Fisika FLUX, 8(2).
Zuidam, R.A.V. 1983. "Guide to Geomorphological Aeral Photographic Interpretation and Mapping". ITC, Enschede, The Nederlands. 
THIS PA GE INTENTIONALLY LEFT BLANK 